\title{
QUALITY COSTING AS A COMPASS IN QUALITY MANAGEMENT
}

\author{
Andrijana Rogošić ${ }^{1}$
}

UDC / UDK: 005.6:006.83:657.05

JEL classification / JEL klasifikacija: M41, P2, L96, O3L15

DOI: https://doi.org/10.22598/pi-be/2020.14.1.11

Original scientific paper / Izvorni znanstveni rad

Received / Primljeno: December 12, 2019 / 12. prosinca 2019.

Accepted for publishing / Prihvaćeno za tisak: March 23, 2020 / 23. ožujka 2020 .

\section{Summary}

Quality Costing is an accounting method that captures and measures qualityrelated costs providing quality data that can be quite useful for quality improvement and management. In order to become relevant source of data in quality management Quality Costing should be properly implemented. Therefore, the scope of quality cost recording and the usage level of Quality Costing determines its maturity level. The purpose of this paper is to explore whether the maturity of Quality Costing positively affects the application of quality management principles according to the ISO 9001:2015. This study reveals that the Quality Costing maturity is crucial in attaining lower level of waste and production nonconformities as well as the failure costs reduction and, on the other hand, the increase of revenues, better decision-making and more sensible investing. Comparing to prior studies the novelty of this paper is in introducing the maturity of accounting system pointing out that more advanced level of Quality Costing application leads to the wider scope of quality data that can be used as a compass in quality management. Empirical research is based on online survey addressed to quality managers. Findings indicate that comprehensive recording and reporting of adequately categorised quality costs can produce many benefits for the organisation.

Key words: Quality Costing, strategic management accounting, ISO 9001, quality management.

\section{INTRODUCTION}

The ISO 9001 standard is often used as an effective tool in quality management and the interest of companies around the globe does not fade since its initial appearance

\footnotetext{
${ }^{1}$ Andrijana Rogošić, Ph.D., Associate Professor, Faculty of Economics, Business and Tourism, University of Split, E-mail: arogosic@efst.hr
} 
in 1987. A steady growth in the number of the globally issued ISO 9001 certificates is noticed worldwide (Gomes Salgado et al., 2016). Due to increasingly competitive business environment many companies relied on quality management systems to respond either to external stakeholder pressures or to internal motivations for changes aiming to increase performance (Murmura et al., 2018: 787). Comparing to the other quality management frameworks, the ISO 9001 was often criticized for its formalisation but the latest, the 2015, version does not even require 'documented procedures'. Astrini (2018) pointed out that process holders are expected to follow the same procedure and this practice can only be achieved using formalisation of the business process (i.e. written procedures and work instructions, formal chain of command, and mandatory documentation of activities). Formalisation and documentation are necessary in accounting. Accounting information is often used to determine the effect of quality management initiatives (Kundid Novokmet and Rogošić, 2017). Accounting data as a segment of financial performance evaluation was thoroughly studied to determine whether it is influenced by quality management (Powell, 1995; Terziovski, Samson and Dow, 1997; Samson and Terziovski, 1999; Dick, 2000; Lima, Resende and Hasenclever, 2000; Staw and Epstein, 2000; Heras, Dick and Casadesus, 2002; Corbett, Montes-Sancho and Kirsch, 2005; Naveh and Marcus, 2005; Morris, 2006; Terlaak and King, 2006; Psomas, Pantouvakis and Kafetzopoulos, 2013; Herzallah, Gutiérrez Gutiérrez and Rosas, 2014; Jaca and Psomas, 2015; Kundid Novokmet and Rogošić, 2017; Astrini, 2018) but the internal use of accounting information as a guide in quality management is scarcely investigated.

This study is focused on Quality Costing as a strategic management accounting method specially designed for the quality oriented companies. Thus, the implementation of Quality Costing in the companies without quality management system is useless. According to Srivastava (2008) cost of quality is the sum of the costs incurred within an organisation in preventing poor quality, the costs incurred to ensure and evaluate that the quality requirements are being met, and any other costs incurred as a result of poor quality. Most commonly used framework to determine the cost of quality is the prevention-appraisal-failure (PAF) model (Shah and Mandal, 1999; Srivastava, 2008; Jaju, Mohanty and Lakhe 2009; Omurgonulsen, 2009; Su, Shi and Lai, 2009; Branca and Catalaõ-Lopes, 2011; Tye, Halim and Ramayah, 2011; Sansalvador and Brotons, 2015; Uyar and Neyis, 2015; Alglawe, Schiffauerova and Kuzgunkaya, 2017) developed by Feigenbaum (1956). According to this model quality costs are classified as prevention, appraisal, internal failure, and external failure costs. The follow up of these costs and the use of this information in quality management can lead to some benefits so the aim of this paper is to determine the effects of Quality Costing implementation. The reminder of the paper is organised as follows. The next section consists of the literature review on quality management principles according to the ISO 9001:2015. Quality Costing as a strategic management accounting method applied in quality-oriented organisations is elaborated in the third section. The review of the prior empirical studies on Quality Costing is given in the fourth section where hypotheses are accordingly formulated. The research methodology is explained in the fifth section 
followed by the results. Finally, concluding remarks with research limitations and recommendations for the future studies are presented in the sixth section.

\section{IMPLEMENTATION OF QUALITY MANAGEMENT PRINCIPLES}

Quality management is based on its principles and according to the ISO 9001:2015 standard these are: 1) Customer focus, 2) Leadership, 3) Engagement of people, 4) Process approach, 5) Improvement, 6) Evidence-based decision-making, and 7) Relationship management. Previously there were eight quality management principles (customer focus, leadership, involvement of people, process approach, system approach to management, continual improvement, factual approach to decision making and mutually beneficial supplier relationships) that formed a framework for the ISO 9001 implementation. The latest revision of this standard incorporated the system approach to management into the process approach. These new principles emphasise performance improvement and organisational excellence through the means of quality management but the differences between previous and new ISO 9001 principles are minimal (Anttila and Jussila, 2017: 1093). All of these quality management principles should be applied respectively in order to achieve success in a long run (Evans, 2008; Bakotić and Rogošić, 2017).

The first quality management principle, costumer focus, can be simply defined as meeting and exceeding customer expectations. The application of customer focus was thoroughly studied even in non-profit organisations and public sector entities like higher education institutions (e.g. Dužević, Mikulić and Baković, 2018). According to Nair (2006) investments in customer complaints evaluation and expectation monitoring systems enable better design of products and processes, so the upgrading of the product quality and operational performance leads to improved financial performance.

Managers (at all levels) should establish unity of purpose and direction and create conditions in which people are engaged in achieving the organization's quality objectives which is referred as leadership (the second principle). Committed leadership in an organisation is essential for successful and enduring quality programmes so the managers play an important role in the quality improvement implementation in the entire company (Bin Abdullah, Uli and Tarí, 2009).

The employees and their skills and knowledge are also in focus of the ISO 9001 so the competent, empowered and engaged people (at all levels throughout the organization) are crucial to the success of quality management system (the third principle). Many authors investigated the engagement of people (Eskildsen and Dahlgaard, 2000; Bin Abdullah et al., 2009; Sila, 2007; Bakotić and Rogošić, 2017) concluding that employees have a crucial role for the success of quality management initiatives.

Process approach refers to the activities that are understood and managed as the interrelated processes functioning as a coherent system in order to optimise the performance (the fourth principle). Biazzo and Bernardi (2003) as well as Carmignani 
(2008) acknowledged the importance of formalisation in this quality management principle application.

Quality management also puts emphasis on continuous improvement (the fifth principle). Fuentes-Fuentes et al. (2004: 429) pointed out that two important benefits come out of continuous improvement: value for customers and elimination of waste (and consequently cost reduction).

Evidence-based decision-making relies on the analysis and evaluation of data and relevant information that are more likely to produce desired results of quality management since the facts lead to a greater objectivity (the sixth principle). Tarí and Sabater (2004) found that the use of quality management tools and techniques as a source of quality data is associated with better results.

An organization should manage its relationships with interested parties such as suppliers in order to sustain the success according to the principle of relationship management. Applying this principle will lead to sharing expertize, resources, information, and future plans with partners, clear and open communication between the organization and its suppliers, and inspiring and recognizing the successes of suppliers (Manders, de Vries and Blind, 2016).

The interdependence of quality management principles was also explored (Kaynak, 2003; Fuentes-Fuentes et al., 2004; Herzallah, Gutiérrez Gutiérrez and Rosas, 2014; Bakotić and Rogošić, 2017) and the empirical research results showed the strong link between them pointing out that all of them should be strongly and thoroughly implemented. The purpose achievement of quality management system relies on the depth and strength of quality management principles application.

\section{QUALITY COSTING}

Quality data analysis involves using quality information tools such as statistical process control and cost of quality measures (Nair, 2006: 971). Quality Costing is an accounting method developed for quality management systems in order to follow up quality-related costs. This strategic management accounting method should be established within the existing accounting system although there is no legal obligation to cover these costs. Quality Costing can be defined as a measurement system that translates quality-related activities into a monetary language used by managers (Srivastava, 2008; Alglawe, Schiffauerova and Kuzgunkaya, 2017). As an accounting method, Quality Costing records and reports on quality costs that are commonly divided into two groups: costs of conformance (prevention and appraisal costs) and costs on non-conformance (internal and external failure costs). In the literature, those costs are often categorised as follows (Omurgonulsen, 2009; Singer and Donoso, 2009; Su et al., 2009; Tye et al., 2011):

- Prevention costs: The costs of the actions taken to investigate prevent and reduce the risks of non-conformity or defect. These costs that result from the efforts of the company during product design and manufacturing that prevent non-conformance to the specifications, like quality planning; quality review 
and verification of design; process planning, quality audits; education and training; quality improvement programmes; quality certification costs.

- Appraisal costs: The costs incurred to determine the degree of conformance to quality requirements, like pre-production verification; laboratory acceptance testing; incoming inspection and tests; in-process inspection and tests; final inspection and tests; field performance testing; inspection and test equipment and all other costs of evaluating the achievement of quality requirements (costs of verification and control performed at any stage of the quality loop).

- Internal failure costs: The costs incurred when poor-quality products are discovered before they are delivered to the customer, like scrap; rework and repair; troubleshooting or defect/failure analysis; re-inspection and retesting; downgrading and all other costs arising within an organisation because of nonconformities or defects at any stage of the quality loop.

- External failure costs: The costs arising after delivery to a customer/user due to nonconformities or defects, which may include the cost of claims against warranty, replacement and consequential losses and evaluation of penalties incurred and all other costs incurred after the customer has received a poorquality product or service (and has taken a proper action).

The increase of costs of conformance could result in the decrease of failure costs in the long-run (and vice versa). This phenomenon is known as trade-off relationship within quality costs (Omurgonulsen, 2009; Su et al., 2009). The quality cost management aims to fully reduce internal and external failure costs. Singer and Donoso (2009) argued that companies should invest more in prevention in order to achieve "zero defect" level and diminish the failure costs.

Shah and Mandal (1999) acknowledged that the most significant problem in measuring quality cost is that of measuring external failure costs. It is not a problem to measure external failure costs like the cost of responding to customer complaints, investigation of customer warranty claims, warranty repairs and replacements, product recalls, product liability, and returns and allowances. Many of these costs are already available in the accounting records, but the single largest measurement problem is measuring the external failure costs associated with lost sales, or customer dissatisfaction, which is not readily available in the accounting system. Those costs (and losses) that cannot be tracked in the accounting system are known as hidden costs of quality. Hidden costs can be among all four categories of quality costs but the most problematic are external failure costs. Alglawe et al. (2017) revealed that most of hidden costs of quality are the opportunity costs which remain unrecorded in the accounting system. Thus, the costs and losses that are not recorded in the accounting system cannot be controlled.

Quality Costing by itself does not improve quality management but the data it provides can be used as a feedback to quality managers that are responsible for quality improvement (Omurgonulsen, 2009; Tye et al., 2011; Pires et al., 2017). Raßfeld, Behmer, Dürlich and Jochem (2015) pointed out that the main motives for the introduction of Quality Costing are: revealing potentials of improvements, creating cost 
transparency and fulfilment of stakeholder requirements. In their literature review, Jafari and Rodchua (2014) stressed out most common benefits of Quality Costing application:

- It could be used as a means for providing estimates of the potential benefits to be gained through quality improvement and it could also help project the monetary benefits and ramifications of the proposed changes;

- It helps evaluate quality programme success and points to the strengths and weaknesses of a quality system;

- It alerts about the potential impact of poor quality on the financial performance of the company;

- It helps organisations determine where quality costs have been incurred and where problems exist and serves as well as a tool for focusing on areas of poor performance in need of improvement;

- It provides corrective action to prevent the occurrence of non-conformances;

- It helps to identify and eliminate organisational activities that do not provide or enhance quality and helps management to determine the types of activities that are more beneficial for reducing quality costs;

- It transfers lessons learned to other areas;

- It focuses attention on the origin of failures and their costs, making those responsible aware and accountable for incurring such costs, thus helping them to become more efficient in their jobs:

- It helps to reduce reworks and thus reduces claims;

- It motivates employees to work towards pursuing quality goals.

Although Quality Costing as an accounting method is known for decades, most of the companies still do not use it, at least not systematically (Tye et al., 2011). Identifying quality costs is a complex task that requires specific accounting knowledge. The real challenge for the accountants is to identify quality costs that are scattered among various head of accounts, especially overheads (Jaju et al., 2009). Quality Costing implementation obstacles that prevent the application of this accounting method are due to (Pires et al., 2017):

- Lack of support or management indifference;

- Management unawareness of the concept and the underlying principles of Quality Costing;

- Out-of-date management philosophy;

- The fact the company is recent and small sized;

- Reduced importance of total company costs;

- The fact that business is profitable and, therefore, there is no pressing need to monitor costs;

- Lack of knowledge regarding how to identify and measure quality costs and the underlying benefits;

- Lack of existence of accounting systems and/or of information and/or information technology attuned to the identification, measurement, filtering and reporting of quality costs; 
- Lack of an appropriate overall categorisation of quality costs and a consequent lack of an accurate classification of the various elements of quality costs within the product life cycle;

- Unawareness and/or uncertainty on behalf of management about the benefits of implementing Quality Costing;

- Quality Costing was not one of the key areas in terms of focusing efforts of the organisation.

Although there are many obstacles for Quality Costing implementation previous empirical studies indicate that it is one of the most widely used strategic management accounting method (Cinquini and Tenucci, 2010; Ramljak and Rogošić, 2012).

\section{HYPOTHESES}

According to Jafari and Rodchua (2014) the absence of cost of quality system has caused many organisations to develop insular ways of quality control which led to uncoordinated quality information gathering and reporting that resulted in wasted time, increase of the errors and (consequently) costs. Thus, more and more practitioners and scholars are acknowledging the imperativeness of the quality costing management and improvement. This tendency is coming from an unprecedented cost down pressure in order to cope with the fierce global competition (Su et al., 2009). Quality Costing has become the most powerful management tool for the measurement of quality performance (Tye et al., 2011) as it provides guidance for quality improvement (Jafari and Rodchua, 2014). Prior studies (Su et al, 2009; Tye et al., 2011; Jafari and Rodchua, 2014) reported various advantages of Quality Costing implementation. Empirical research results indicate that Quality Costing implementation leads to the reduction of customer complaints, rework and scrap as well as failure costs (Sower, Quarles and Broussard, 2007; Tye et al., 2011). Sower et al. (2007) pointed out that external failure costs declined as a percentage of total cost of quality as an organization's quality system matures. Giakatis and Rooney (2000) found that Quality Costing implementation positively affected organisational performance due to easier the bottom-up and topdown communication regarding the quality issues. This led to better understanding of processes so the employees were able to identify nonconformities and take improvement measures. Tye et al. (2011) reported the increase of sales volume after the implementation of Quality Costing. Also, Quality Costing has an effect on the operating costs, profitability, and consumer needs (Srivastava, 2008). All of the above mentioned studies had empirical results that inspired the following hypotheses formulation:

$\mathrm{H}_{1}$ : Companies that apply Quality Costing rely more on accounting information in quality management.

$\mathrm{H}_{2}$ : Quality Costing positively affects profitability.

$\mathrm{H}_{3}$ : Quality Costing enables greater overall organisational performance. 
$\mathrm{H}_{4}$ : Maturity of Quality Costing is positively linked with the application of the ISO 9001 quality management principles.

$\mathrm{H}_{5}$ : Maturity of Quality Costing is positively linked to: lower level of waste and production nonconformity, reduction of failure costs, increase of revenues, better decision-making and sensible investments.

\section{METHODOLOGY AND RESULTS}

The design of the measurement instrument was based on the literature review. The items were adopted from similar surveys (Tye et al., 2011; Alglawe et al., 2017) and adjusted to the ISO 9001 framework. A 1-5 Likert scale was used for the items that measured the level of implementation of quality management principles and Quality Costing where 1 was "insufficient" and 5 was "excellent".

The target population of this study was the ISO 9001 certified companies in Croatia. The link to the online survey was sent to e-mail addresses of 945 companies where it was indicated that the targeted informants were quality managers. The questionnaire was filled out by 106 quality managers during July 2019.

The collected data was analyzed using the SPSS program. The Mann-Whitney and Jonckheere-Terpstra tests are performed to validate the hypotheses.

The first three hypotheses were tested using Quality Costing as an independent (grouping) variable in the Mann-Whitney test (Table 1).

Table 1. Mann-Whitney test - effects of Quality Costing system implementation

\begin{tabular}{|l|r|r|r|}
\hline & $\begin{array}{c}\text { Relying on } \\
\text { accounting } \\
\text { information }\end{array}$ & \multicolumn{1}{|c|}{$\begin{array}{c}\text { Profitability } \\
\text { increase }\end{array}$} & \multicolumn{1}{c|}{$\begin{array}{l}\text { Overall } \\
\text { performance }\end{array}$} \\
\hline Mann-Whitney U & 797.500 & 803.000 & 718.000 \\
\hline Wilcoxon W & 2175.500 & 2129.000 & 2096.000 \\
\hline Z & -2.160 & -2.039 & -2.709 \\
\hline Asymp. Sig. (2-tailed) & .031 & .041 & .007 \\
\hline a. Grouping Variable: QC
\end{tabular}

Source: Author's calculation

The results (Table 1) indicate that companies with Quality Costing system (comparing to the others without Quality Costing) rely more on accounting information in quality management which enables them to be more profitable and achieve better organizational performances. These findings are similar those of Giakatis and Rooney (2000) and Srivastava (2008). This finding sheds light on the role of the accounting system in quality management. Recently, accounting is considered as a good source of 
quality-related data that can be properly used in achieving greater performance as well as profitability.

Since Quality Costing can be used thoroughly or, on the other hand, less profoundly the assessment (using 5-point Likert scale) of the maturity level was crucial. Only 52 quality managers evaluated the Quality Costing system. Most of them (40\%) reported that their Quality Costing system is very well developed (level 4) and 29\% agreed that their Quality Costing system is on the level 3 while only 13\% found it excellent (or fully mature). The minority of the respondents assessed their Quality Costing system as inadequate since $6 \%$ claimed that the system is on the second level of maturity and $12 \%$ found it insufficiently developed. The mean value of Quality Costing system maturity was 3.38 so the observed companies have much to do in order to achieve the full potential of this accounting method.

The companies can differently include and record quality costs so the scope of quality cost follow up and the usage level of this accounting data determines the maturity (development stage) of Quality Costing. Therefore, Quality Costing Maturity refers to the effective use of quality costs information. The Jonckheere-Terpstra test was performed in order to determine if the mature Quality Costing system enables better implementation of quality management principles to ISO 9001:2015 (Table 2).

Table 2. Jonckheere-Terpstra test - Quality Costing system maturity and quality principles

\begin{tabular}{|c|c|c|c|c|c|c|c|}
\hline & customer & leadership & employees & process & factual & continuous & mutual \\
\hline $\begin{array}{l}\text { Number of } \\
\text { Levels in QC } \\
\text { maturity }\end{array}$ & 5 & 5 & 5 & 5 & 5 & 5 & 5 \\
\hline $\mathrm{N}$ & 52 & 52 & 52 & 52 & 51 & 52 & 49 \\
\hline $\begin{array}{l}\text { Observed J-T } \\
\text { Statistic }\end{array}$ & 558.000 & 648.000 & 666.000 & 610.500 & 589.000 & 661.500 & 568.000 \\
\hline $\begin{array}{l}\text { Mean J-T } \\
\text { Statistic }\end{array}$ & 486.000 & 486.000 & 486.000 & 486.000 & 470.500 & 486.000 & 426.500 \\
\hline $\begin{array}{l}\text { Std. Deviation of } \\
\text { J-T Statistic }\end{array}$ & 50.531 & 52.240 & 56.159 & 56.652 & 55.331 & 56.558 & 50.570 \\
\hline Std. J-T Statistic & 1.425 & 3.101 & 3.205 & 2.198 & 2.142 & 3.103 & 2.798 \\
\hline $\begin{array}{l}\text { Asymp. Sig. (2- } \\
\text { tailed) }\end{array}$ & .154 & .002 & .001 & .028 & .032 & .002 & .005 \\
\hline
\end{tabular}

Source: Author's calculation

The results (Table 2) revealed that companies with the more mature Quality Costing system have implemented better the ISO 9001 quality management principles (except customer focus). Leadership (labelled as leadership in Table 2), Engagement of 
people (labelled as employees), Process approach (labelled as process), Improvement (labelled as continuous), Evidence-based decision-making (labelled as factual), and Relationship management (labelled as mutual) are found significantly affected by Quality Costing system maturity. As before mentioned Quality Costing can offer valuable information that leads to better insight in the strengths and weaknesses of quality management so that all quality principles could be profoundly implemented. Thus the full potential of Quality Costing usage can provide guidelines not only for continual improvement and process approach but also for better leadership and greater employee involvement (since the people use quality data in their work and decisionmaking processes) that can result in more advanced relationship with suppliers and the other interested parties. Since Quality Costing is a tool in evidence-based decisionmaking the positive effect on this quality management principle application is evidently clear.

The fifth hypothesis regarding the effect of the mature Quality Costing system on lower level of waste and production nonconformity, reduction of failure costs, increase of revenues, better decision-making and sensible investments was confirmed using Jonckheere-Terpstra test (Table 3) since p-value in all cases is less than 0.05 .

Table 3. Jonckheere-Terpstra test - effects of Quality Costing system maturity

\begin{tabular}{|l|r|r|r|r|r|}
\hline & waste & \multicolumn{1}{|c|}{$\begin{array}{c}\text { failure } \\
\text { costs }\end{array}$} & revenue & $\begin{array}{c}\text { decision- } \\
\text { making }\end{array}$ & investment \\
\hline $\begin{array}{l}\text { Number of Levels in } \\
\text { QC maturity }\end{array}$ & 5 & 5 & 5 & 5 & 5 \\
\hline $\mathrm{N}$ & 570.500 & 533.000 & 533.500 & 544.500 & 559.000 \\
\hline $\begin{array}{l}\text { Observed J-T } \\
\text { Statistic }\end{array}$ & 417.000 & 417.000 & 417.000 & 417.000 & 417.000 \\
\hline Mean J-T Statistic & 51.746 & 50.226 & 52.002 & 50.578 & 51.927 \\
\hline $\begin{array}{l}\text { Std. Deviation of J-T } \\
\text { Statistic }\end{array}$ & 2.966 & 2.310 & 2.240 & 2.521 & 2.735 \\
\hline Std. J-T Statistic & .003 & .021 & .025 & .012 & .006 \\
\hline $\begin{array}{l}\text { Asymp. Sig. (2- } \\
\text { tailed) }\end{array}$ & & & & \\
\hline a. Grouping Variable: QC maturity & & & & & \\
\hline
\end{tabular}

Source: Author's calculation

The findings (Table 3) are in line with the prior studies (Sower, Quarles and Broussard, 2007; Tye et al., 2011) at least when lower level of waste and production nonconformity and reduction of failure costs are considered. On the other hand, Nair (2006) claimed that his study could not find a direct relationship of quality data analysis with financial performance, operational performance and product quality. Also Sower et al. (2007) acknowledged that sales and profit growth were not significantly correlated 
with the presence of a quality cost system or with the level of maturity of the quality system. The increase of revenues as the effect of Quality Costing implementation is also reported in the work of Tye et al. (2011). The empirical research results of this study (Table 3) showed that higher level of Quality Costing implementation leads to the increase of revenues, better decision-making and smarter investments. Thus, it is not enough just to apply Quality Costing. This strategic management accounting method should be adequately implemented with the proper categorisation of the quality costs, follow up and reporting. More mature Quality Costing system can provide more relevant quality-oriented accounting information and consequently (when this information is well used) enable better decisions that positively affect sales growth.

\section{CONCLUDING REMARKS}

Quality-oriented companies in Croatia often apply the ISO 9001 standard as a framework for quality management. The popularity of the ISO 9001 is not fading due to many benefits its implementation brings. In order to manage and control better the quality of the processes and outputs, companies often apply Quality Costing as an effective accounting method in quality improvement. This strategic management accounting method is specially designed for the organisations that implemented the quality management system. The prevention-appraisal-failure (PAF) model is the most widely used framework of the identification and categorisation of the quality costs even though it was criticised for its limitations. The scope of quality cost recording and the usage level of Quality Costing determines the development stage (maturity) that reflects on quality-data utilisation. Although application of Quality Costing brings many benefits such as greater overall performance and profitability, the maturity of this accounting method is found to be relevant in achieving advanced and comprehensive quality management.

Comparing to the prior studies this one is focused on the application of quality management principles according to the ISO 9001 framework as a result of Quality Costing maturity. The contribution of this paper is in the overview on the effects on each quality management principle application regarding the maturity level of Quality Costing. Thus, the more mature Quality Costing is the more relevant quality data it provides. This kind of quality data can be used for in-depth implementation of the quality principles in order to achieve better quality management.

Previous studies (Giakatis and Rooney; 2000; Nair, 2006; Sower et al., 2007; Tye et al., 2011) have somewhat contradictory empirical results regarding the effects of Quality Costing. This study sheds light on the cause why the simple application of Quality Costing does not always have the same results. The reason behind this is the maturity level of Quality Costing. So, follow up of the complete quality costs, their proper categorisation, reporting and understanding can lead to lower level of waste and production nonconformity and, consequently, the reduction of failure costs (as a result of the trade-off within quality costs) and, also, to the increase of revenues and better decision-making as well as more sensible investments. When appropriately used Quality 
Costing can be an effective source of quality data and a good compass in quality management.

Although there are many empirical papers on quality-related costs, this study contributes to scarce literature on Quality Costing especially when maturity of this strategic management accounting method is considered. The sample size is one of the limitations of this research. The other limitation is related to the scope of explored effects of Quality Costing maturity. Thus, the recommendation for the future research is to introduce various dependent variables regarding concrete examples of quality management practices in order to determine whether they are affected by Quality Costing maturity.

\section{REFERENCES}

1. Alglawe, A., Schiffauerova, A. \& Kuzgunkaya, O. (2017). Analysing the cost of quality within a supply chain using system dynamics approach. Total Quality Management \& Business Excellence, DOI: 10.1080/14783363.2017.1400376

2. Anttila, J. \& Jussila, K. (2017). ISO 9001:2015 - a questionable reform. What should the implementing organisations understand and do?. Total Quality Management \& Business Excellence, 28(9-10), 1090-1105. DOI: $10.1080 / 14783363.2017 .1309119$

3. Astrini, N. (2018). ISO 9001 and performance: a method review. Total Quality Management \& Business Excellence, DOI: 10.1080/14783363.2018.1524293

4. Bakotić, D. \& Rogošić, A. (2017). Employee involvement as a key determinant of core quality management practices. Total Quality Management \& Business Excellence, 28(11-12), 1209-1226. DOI: 10.1080/14783363.2015.1094369

5. Biazzo, S. \& Bernardi, G. (2003). Process management practices and quality systems standards: Risks and opportunities of the new ISO 9001 certification. Business Process Management Journal, 9(2). 149-169.

6. Bin Abdullah, M.M., Uli, J. \& Tarí, J.J. (2009). The relationship of performance with soft factors and quality improvement. Total Quality Management \& Business Excellence, 20(7), 735-748. DOI: $10.1080 / 14783360903037051$

7. Branca, A.S. \& Catalão-Lopes, M. (2011). Strategic interaction and quality choice. Total Quality Management \& Business Excellence, 22(3), 265-273. DOI: $10.1080 / 14783363.2010 .530809$

8. Carmignani, G. (2008). Process-based management: A structured approach to provide the best answers to the ISO 9001 requirements. Business Process Management Journal, 14(6), 803-812.

9. Cinquini, L. \& Tenucci, A. (2010). Strategic management accounting and business strategy: a loose coupling?. Journal of Accounting and Organizational Change, 6 (2), 228-259. 
10. Corbett, C., Montes-Sancho, M. \& Kirsch, D. (2005). The financial impact of ISO 9000 certification in United States: an empirical analysis. Management Science, 51(7), 1046-1059.

11. Dick, G. P. M., 2000. ISO 9000 certification benefits, reality or myth? The TQM Magazine, 12(6), 365-371.

12. Dužević, I, Mikulić, J. \& Baković, T. (2018). An extended framework for analysing higher education performance. Total Quality Management \& Business Excellence, 29(5-6), 599-617. DOI: 10.1080/14783363.2016.1224083

13. Eskildsen, J.K. \& Dahlgaard, J.J. (2000). A causal model for employee satisfaction. Total Quality Management, 11(8):1081-1094. DOI: $10.1080 / 095441200440340$

14. Evans, J. R., 2008. Quality and performance excellence - management, organization and strategy. 5th ed. Mason $(\mathrm{OH})$ : South-Western.

15. Feigenbaum, A.V. (1956). Total Quality Control. Harvard Business Review, 34(6), 93-101.

16. Fuentes-Fuentes, M.M., Albacete-Sáez, C.A., Lloréns-Montes, F.J. (2004). The impact of environmental characteristics on TQM principles and organizational performance. Omega, 32, 425-442.

17. Giakatis, G. \& Rooney, E.M. (2000): The use of quality costing to trigger process improvement in an automotive company, Total Quality Management, 11(2), 155-170.

18. Gomes Salgado, E., Beijo, L. A., Sampaio, P., Pereira Mello, C. H. \& Saraiva, P. (2016). ISO 9001 certification in the American Continent: a statistical analysis and modelling. International Journal of Production Research, 54(18), 5416-5433. DOI: 10.1080/00207543.2015.1109719

19. Heras, I., Dick, G. \& Casadesus, M. (2002). ISO 9000 registration's impact on sales and profitability: a longitudinal analysis of performance before and after accreditation. The International Journal of Quality \& Reliability Management, 19, 774-791.

20. Herzallah, A. M., Gutiérrez Gutiérrez, L. \& Rosas, J. F. M. (2014). Total quality management practices, competitive strategies and financial performance: the case of Palestinian industrial SMEs. Total Quality Management \& Business Excellence, 25(5/6), 635-649.

21. Jaca, C. \& Psomas, E. (2015). Total quality management practices and performance outcomes in Spanish service companies. Total Quality Management \& Business Excellence, 26(9), 958-970. DOI: $10.1080 / 14783363.2015 .1068588$

22. Jafari, A. \& Rodchua, S. (2014). Survey research on quality costs and problems in the construction environment. Total Quality Management \& Business Excellence, 25(3-4), 222-234. DOI: 10.1080/14783363.2013.824715

23. Jaju, S. B. Mohanty, R. P. \& Lakhe, R. R. (2009). Towards managing quality cost: A case study. Total Quality Management \& Business Excellence, 20(10), 1075-1094. DOI: $10.1080 / 14783360903247122$ 
24. Kaynak, H., (2003). The relationship between total quality management practices and their effects on firm performance, Journal of Operations Management, 21, 405-435.

25. Kundid Novokmet, A. \& Rogošić, A. (2017). Long-term financial effects of quality management system maturity based on ISO 9001 principles. Amfiteatru Economic, 19(Special No. 11), 1003-1016.

26. Lima, M., Resende, M. \& Hasenclever, L. (2000). Quality certification and performance of Brazilian firms: an empirical study. International Journal of Production Economics, 66, 143-147.

27. Manders, B., de Vries, H.J. \& Blind. K. (2016). ISO 9001 and product innovation: A literature and research framework. Technovation, 48-49. 41-55.

28. Morris, P. W. (2006). ISO 9000 and financial performance in the electronics industry. Journal of American Academy of Business, 8(2), 227-235.

29. Murmura, F., Casolani, N., Liberatore, L. \& Vicentini, A. (2018). An empirical analysis of ISO 9001:2008 application in Italian services and manufacturing companies. Total Quality Management \& Business Excellence, 29(7-8), 786797. DOI: $10.1080 / 14783363.2016 .1237286$

30. Nair, A. (2006). Meta-analysis of the relationship between quality management practices and firm performance: Implications for quality management theory development. Journal of Operations Management, 24, 948-975.

31. Naveh, E. \& Marcus, A., 2005. Achieving competitive advantage through implementing a replicable management standard: installing and using ISO 9000. Journal of Operations Management, 24(1), 1-26.

32. Omurgonulsen, M. (2009). A research on the measurement of quality costs in the Turkish food manufacturing industry. Total Quality Management, 20(5), 547-562. DOI: 10.1080/14783360902863739

33. Pires, A.R., Novas, J., Saraiva, M. \& Coelho, A. (2017). How companies use the information about quality-related costs. Total Quality Management \& Business Excellence, 28(5-6), 501-521. DOI: 10.1080/14783363.2015.1099427

34. Powell, T. C., 1995. Total quality management as competitive advantage: A review and empirical study. Strategic Management Journal, 16, 15-37.

35. Psomas, E.L., Pantouvakis, A. \& Kafetzopoulos, D.P. (2013). The impact of ISO 9001 effectiveness on the performance of service companies. Managing Service Quality. 23(2), 149-164. DOI: 10.1108/09604521311303426

36. Ramljak, B. \& Rogošić, A. (2012). Strategic management accounting practices in Croatia. Journal of International Management Studies, 7(2), 93-100.

37. Raßfeld, C., Behmer, F., Dürlich, M. \& Jochem, R. (2015). Do quality costs still matter?. Total Quality Management \& Business Excellence, 26(10), 10711082. DOI: $10.1080 / 14783363.2015 .1068591$

38. Samson, D. \& Terziovski, M. (1999). The relationship between total quality management practices and operational performance. Journal of Operations Management, 17, 393-409.

39. Sansalvador, M. E., \& Brotons, J. M. (2015). Valuation of the option of abandoning ISO 9001 certification: An empirical study in Spain. Total Quality 
Management \& Business Excellence, 26(12), 1255-1268. DOI: $10.1080 / 14783363.2014 .929231$

40. Shah, K \& Mandal, P. (1999). Issues related to implementing quality cost programmes. Total Quality Management, 10(8), 1093-1106. DOI: $10.1080 / 0954412997082$

41. Sila, I. (2007). Examining the effects of contextual factors on TQM and performance through the lens of organizational theories: An empirical study. Journal of Operations Management, 25(1), 83-109.

42. Singer, M. \& Donoso, P. (2009). If prevention is better than cure, why do firms do the opposite?. Total Quality Management \& Business Excellence, 20(9), 905-919. DOI: 10.1080/14783360903181578

43. Sower, V. E., Quarles, R. \& Broussard, E. (2007). Cost of quality usage and its relationship to quality system maturity. International Journal of Quality \& Reliability Management, 24(2), 121-140.

44. Srivastava, S.K. (2008). Towards estimating Cost of Quality in supply chains, Total Quality Managemen t\& Business Excellence, 19(3), 193-208. DOI: 10.1080/14783360701600605

45. Staw, B. \& Epstein, L. D. (2000). What bandwagons bring: effects of popular management techniques on corporate performance, reputation and CEO pay. Administrative Science Quarterly, 45, 523-556.

46. Su, Q. Shi, J-H. \& Lai, S-J. (2009). Research on the trade-off relationship within quality costs: A case study. Total Quality Management \& Business Excellence, 20(12), 1395-1405. DOI: 10.1080/14783360903248922

47. Tarí, J.J. \& Sabater, V. (2004). Quality tools and techniques: Are they necessary for quality management? International Journal of Production Economics, 92, 267-280.

48. Terlaak, A. \& King, A. A. (2006). The effect of certification with the ISO 9000 quality management standard: a signaling approach. Journal of Economic Behavior and Organization, 60(4), 579-602.

49. Terziovski, M., Samson, D. \& Dow, D. (1997). The business value of quality management systems certification: evidence from Australia and New Zealand. Journal of Operations Management, 15, 1-18.

50. Tye, L.H., Halim, H.A. \& Ramayah, T. (2011). An exploratory study on cost of quality implementation in Malaysia: The case of Penang manufacturing firms. Total Quality Management \& Business Excellence, 22(12), 1299-1315. DOI: $10.1080 / 14783363.2011 .625191$

51. Uyar, A. \& Neyis, A. (2015). Does the healthcare industry report quality costs?. Comparative investigations of public and private hospitals. Total Quality Management \& Business Excellence, 26(7-8), 733-745. DOI: $10.1080 / 14783363.2014 .882003$ 


\title{
RAČUNOVODSTVO TROŠKOVA KVALITETE KAO KOMPAS U UPRAVLJANJU KVALITETOM
}

\author{
Andrijana Rogošić
}

\begin{abstract}
Sažetak
Računovodstvo troškova kvalitete je računovodstvena metoda kojom se obuhvaćaju I mjere troškovi glede kvalitete omogućujući podatke o kvaliteti koji mogu biti korisni prilikom poboljšanja kvalitete i upravljanja istom. Kako bi bilo relevantan izvor podataka o kvaliteti, računovodstvo troškova kvalitete bi trebalo biti adekvatno implementirano. Prema tome, obuhvat troškova kvalitete $i$ razina korištenja računovodstva troškova kvalitete određuje stupanj zrelosti samog sustava. Svrha ovog rada je istražiti da li zrelost računovodstva troškova kvalitete pozitivno utječe na primjenu načela upravljanja kvalitetom sukladno ISO 9001:2015. Ovo istraživanje otkiva ključan utjecaj zrelosti računovodstva troškova kvalitete na smanjenje otpadaka $i$ nesukladnosti u proizvodnji kao i troškova nedostataka te, s druge strane, na povećanje prihoda, donošenje boljih poslovnih odluka i razumno investiranje. Uspoređujući s prethodnim istraživanjima novost ovoga je u uvođenju zrelosti računovodstvenog sustava s naglaskom na to da viša razina primjene računovodstva troškova kvalitete omogućuje veći opseg podataka o kvaliteti koji mogu biti korišteni kao kompas u upravljanju kvalitetom. Empirijsko istraživanje se temelji na anketi putem Interneta upućenoj menadžerima kvalitete. Rezultati upućuju na zaključak da sveobuhvatna evidencija prethodno adekvatno kategoriziranih troškova kvalitete omogućuje brojne koristi za organizaciju.
\end{abstract}

Ključne riječi: računovodstvo troškova kvalitete, strateško menadžersko računovodstvo, ISO 9001, upravljanje kvalitetom. 